\title{
The Effects of the Macroprudential Policies on Turkish Banking Sector ${ }^{1}$
}

\author{
Murat MAHMUTOĞLU iD a Hakan Naim ARDOR iD $b$ \\ a Republic of Turkey Ministry of Industry and Technology, Ankara, Turkey. muratmahmutoglu@hotmail.com \\ b Ankara Hacı Bayram Veli University, Faculty of Economics and Administrative Sciences, Ankara, Turkey. hakan.ardor@hbv.edu.tr
}

\begin{tabular}{ll}
\hline ARTICLE INFO & ABSTRACT \\
\hline Keywords: & $\begin{array}{l}\text { Purpose - The aim of the research is to test the effectiveness of macroprudential policies that contain } \\
\text { different instruments and help to ensure financial stability in Turkey. }\end{array}$ \\
Macroprudential policies & Design/methodology/approach - The Central Bank of Turkey (CBRT) and the Banking Regulation \\
Fragility & and Supervision Agency (BRSA) implemented macroprudential policies such as active use of Debt \\
& to Income (DTI), Loan to Value ratio (LTV), required reserve ratios, capital requirement, foreign \\
Received 21 June & vulnery lending limits, credit growth limits, interest rate corridor in order to mitigate financial \\
Revised 13 October & methods in the paper. The data consist banking groups that are Turkish banking sector, deposit \\
Accepted 25 October & banks, development\&investment banks. \\
& $\begin{array}{l}\text { Results - Empirical findings show that tightening macroprudential policies reduce the loan growth } \\
\text { of the Turkish Banking sector and deposit banks. However, the magnitude of this effect is relatively } \\
\text { small. Unlike these findings, the effects of macro-prudential tools on the loan growth for the Turkish } \\
\text { Development\&Investment Banks are not significant statistically. } \\
\text { Research Article } \\
\text { Discussion - Aftermath of the global crisis, the new monetary policy, which doesn't have traditional } \\
\text { features, started to be implemented from the middle of } 2010 \text { and has been going on as of the } \\
\text { beginning of } 2019 \text { in Turkey. Accordingly, the Central Bank of Turkey (CBRT) has determined } \\
\text { financial stability as a goal in addition to price stability in the framework of the new monetary policy } \\
\text { and it has carried out and developed new tools in accordance with this secondary objective. This } \\
\text { application has been carried out in coordination with (BRSA). The new monetary policy of the CBRT } \\
\text { and the macro-prudential policies of the BRSA mutually aimed to mitigate financial vulnerabilities } \\
\text { and provide financial stability in Turkey. When we examine and interpret the empirical results, we } \\
\text { can say that the macro-prudential policy tools affect a certain degree of credit growth in the whole } \\
\text { banking system. However, this effect is not very strong. }\end{array}$ \\
\end{tabular}

\section{Introduction}

The 2008 crisis, which emerged from the mortgage financing system in the United States and then turned into a global financial crisis, has begun to question the monetary policy practices of price stabilization, which are based only on the purpose of stabilizing the prices of goods and services. Because, in this system, the price stability of real estate such as housing, land and financial assets such as stocks, bonds and bonds has been ignored. The financial crisis that originated from the United States and then spread to Europe and gained a global property showed the importance of stability of the asset prices.

After the global financial crisis, the United States, the European Union and Japanese have implemented highly expansionary monetary policies called quantitative easing. After 2009, since interest rates are relatively low in these countries, there was quite high levels of capital inflows to developing countries such as Turkey. These quite capital inflows cause to overvalue the Turkish Lira. This induced to high capital account deficits and excessive loan growth in the banking system. The high rate of loan growth in the banking sector, the extreme

\footnotetext{
1 This paper was presented at 4th International Conference on Banking and Finance Perspectives held in Famagusta-North Cyprus between 2-3 May 2019.

* The views presented in the paper are entirely the author's. Therefore, it does not represent the views of the ministry. 
volatility of short-term foreign capital movements and the high-unsustainability of current account deficits have all led as financial fragility indicators and threats to financial stability in Turkey.

There are 52 banks that operates actively in Turkey in 2019. Of these banks, 34 are deposit banks, 13 are development and investment, and 5 are islamic banks. Considering that gross domestic product, population level, of Turkey, the sector's asset size, loans and deposits, we can say that the number of banks that actively operate is relatively low and the Turkish banking system has an oligopolistic structure. This situation creates some monopolistic feature in determining the loan and deposit rates. Due to all these characteristics, some regulations regarding the sector may not give results like developed countries where the banking sector is more competitive.

The purpose of the paper is to investigate that Central Bank of Turkey (CBRT) has been implementing whether the monetary policy, which uses simultaneously different tools and adopts financial stability as a primary aim as well as price stability since mid-2010. At the same time, the effects of the macro-prudential tools that has been applied by The Banking Regulation and Supervision (BRSA) have been analyzed and tested with the econometric time series methods. The numerical results that has been obtained and examined whether they are compatible with the economic expectations.

\section{Macroprudential Framework}

Macroprudential policies are tools that are applied to restrain potential systemic financial risks and complement them simultaneously with traditional macroeconomic policies. Although these policies have been implemented to a certain extent since the 1990s, they were mainly used after the global financial crisis. The main purpose of these policies is to contribute to financial stability by preventing the excessive borrowing of firms and households in the country. At the same time, it is to ensure that the financial services in the country are carried out properly and consistently in the face of internal and external shocks to which the economy is exposed. However, the objectives of the policies may differ in developed and developing countries.

The main objective of macroprudential policies in developed countries is to prevent excessive credit growth and the associated financial bubbles. That is, in order to hinder the excessive increase in the prices of securities and real estate in the country, and so to mitigate the financial fragilities of the countries.

Extreme expansionary monetary policies implemented in developed countries immediately after the global crisis increased the flow of funds to developing countries. This situation has created great imbalances in the economies of these countries. The most prominent of these imbalances is the overvaluation of national currency away from the realities of the country's economy. This large amount of capital inflows created an abundance of foreign currency in the country and made the national currency invaluable. This situation both increased the current account deficit of the country and led to rapid increases in loan growth.

Macro-prudential policy instruments were explained elaborately at International Monetary Fund (IMF) survey, called Global Macro-prudential Policy Instruments (GMPI) in 2011. These policy instruments, which are explained in detail by the IMF, are widely accepted globally. IMF survey contains 12 different instruments

: General Countercyclical Capital Buffer/Requirement (CTC), Leverage Ratio for banks (LEV), TimeVarying/Dynamic Loan-Loss Provisioning (DP), Loan to Value Ratio (LTV), Debt to Income Ratio (DTI), Limits on Domestic Currency Loans (CG), Limits on Foreign Currency Loans (FC), Reserve Requirement Ratios (RR), Levy/Tax on Financial Institutions (TAX), Capital Surcharges on SIFIs (SIFI), Limits on Interbank Exposures (INTER) and Concentration Limits (CONC) (Cerutti et al.,2015).

According to a Bank of International Settlements (BIS) working paper which was published in 2007, classified macro-prudential policies in five different categories : capital based instruments, liquidity based instruments, asset-side instruments, reserve requirements, currency requirements. (Altunbaş et al.,2017).

\section{New Monetary Policy and Macroprudential Policies Applied By The Central Bank of Turkey}

Central Bank of the Republic of Turkey (CBRT) implemented inflation targeting monetary policy regime from 2002 to 2010. This regime was to achieve price stability only. Short-term interest rate was used as the main monetary policy instrument in this regime. The global financial crisis has shown that ignoring financial stability will threaten macroeconomic stability and price stability. The financial risks accumulated with the balloons in the asset prices showed that only price stability is not sufficient and financial stability also should 
be established in the whole economy. However, it is not possible for central banks to control more than one variable with a single tool.

As in many other developing countries in the aftermath of the global crisis, there was a considerable amount of short term foreign capital inflows to Turkey. The characteristics of this capital were that they were in search of high return.

The gross domestic product (GDP) of Turkey, which shrank by 4,8\% in 2009 due to the impact of the global financial crisis, grew by $8,9 \%$ thanks to the high amount of foreign capital inflow in 2010. Developed countries implemented highly expansionary tightening monetary policies by decreasing interest rates to historic low levels in order to get out of the recession created by the global crisis. In such cases, it provides a high amount of capital inflows to developing countries (emerging markets) such as Turkey after the year 2009. In addition, net portfolio investment inflow to Turkey, which was only 0.2 billion dollars in 2009, rose to 16.1 billion dollars in 2010. While the ratio of current account deficit to GDP was $1.8 \%$ in 2009 , it increased to $6.1 \%$ in 2010 , due to the high capital inflows that overvalued the Turkish Lira. In the same period, the rate of increase in the total loan in the banking sector, which was $6.9 \%$, increased to $33.9 \%$. All these developments have led the central bank to take precautions regarding the financial stability that has begun to deteriorate.

The new monetary policy, which doesn't have traditional features, started to be implemented from the middle of 2010. Accordingly, the CBRT has determined financial stability as a goal in addition to price stability in the framework of the new monetary policy and it has carried out and developed new tools in accordance with the aim of financial stability. Central banks can't control more than one variable with a single tool. Therefore, CBRT has set two intermediate targets to mitigate the accumulated macro financial risks. These targets are to reduce short-term capital inflows and slow down loan growth. In this respect, in addition to short term interest rate, the CBRT have carried out two monetary policy instruments. These instruments are required reserves and interest rate corridor. (Başçı \& Kara, 2011)

In this framework, firstly, the CBRT aimed to deter capital inflows by keeping short-term policy interest rate low. When we look the Figure 1, we can comprehend this policy implementation. With the reduction of volatility in capital inflows, it is aimed to eliminate the extreme deterioration in the current account balance. Secondly, the CBRT aimed to slow down the loan growth rate by increasing the required reserve ratios. Thirdly, the CBRT extended the interest rate corridor, which represents the difference between overnight lending and borrowing interest rates. The expansion of the interest rate corridor was implemented in order to create uncertainty in the formation of the weighted average interest rate of the CBRT. It was thought that this uncertainty would contribute to mitigate not only the excessive short-term capital inflows, but also the banking sector's loan growth. The expansion of the interest rate corridor has been an effective part of the central bank's liquidity management strategy. Reserve requirements and the interest rate corridor may also be referred macro-prudential policy tools in Turkey.

One of the tools that has been developed by CBRT in order to limit the negative effects of excessive volatility in capital movements on macroeconomic and financial stability is reserve option mechanism. This mechanism allows banks to establish a certain percentage of reserve requirements for Turkish Lira in foreign currency or gold. The mechanism constructed as an automatic stabilizer application can also be referred to as a macroprudential policy tool in Turkey.

The CBRT continued to use the policy interest rate as a monetary policy tool for the purpose of price stability in 2010 and beyond. Besides, the CBRT implemented macro-prudential policies such as active use of required reserve ratios, reserve option mechanism, interest rate corridor, active liquidity management in which the market funding composition and maturity are persistently changed and in order to reduce financial fragilities.

In order to restrain the loan growth rate of over $30 \%$ in 2010, the central bank began to increase the ratio of required reserves from the last months of the year. (see Figure 2) Although the effective rate of Turkish Lira deposits subject to required reserve, which were implemented at $5 \%$ level in September 2010, increased to 13\% in June 2011, the total loan growth rate was 36,4\% and still higher than \%30 in June 2011. After realizing that the required reserve ratios were insufficient in limiting the loan growth, Banking Regulation and Supervision Agency (BRSA) was activated. In June 2011, the BRSA began to implement credit tightening tools as an aid to the CBRT. The BRSA began to carry out "increased general provisioning for consumer loans (apart from 
H. Ardor - M. Mahmutoğlu 11/4 (2019) 2371-2383

housing and vehicle loans)" 2 . At the end of 2011, the annual growth rate of loans decreased below $30 \%$ after the BRSA became actively. (see Figure 3) As a result, in order to the implement an effective monetary policy, appropriate macro prudential policies should be simultaneously carried out by the BRSA. (Özatay, 2012)

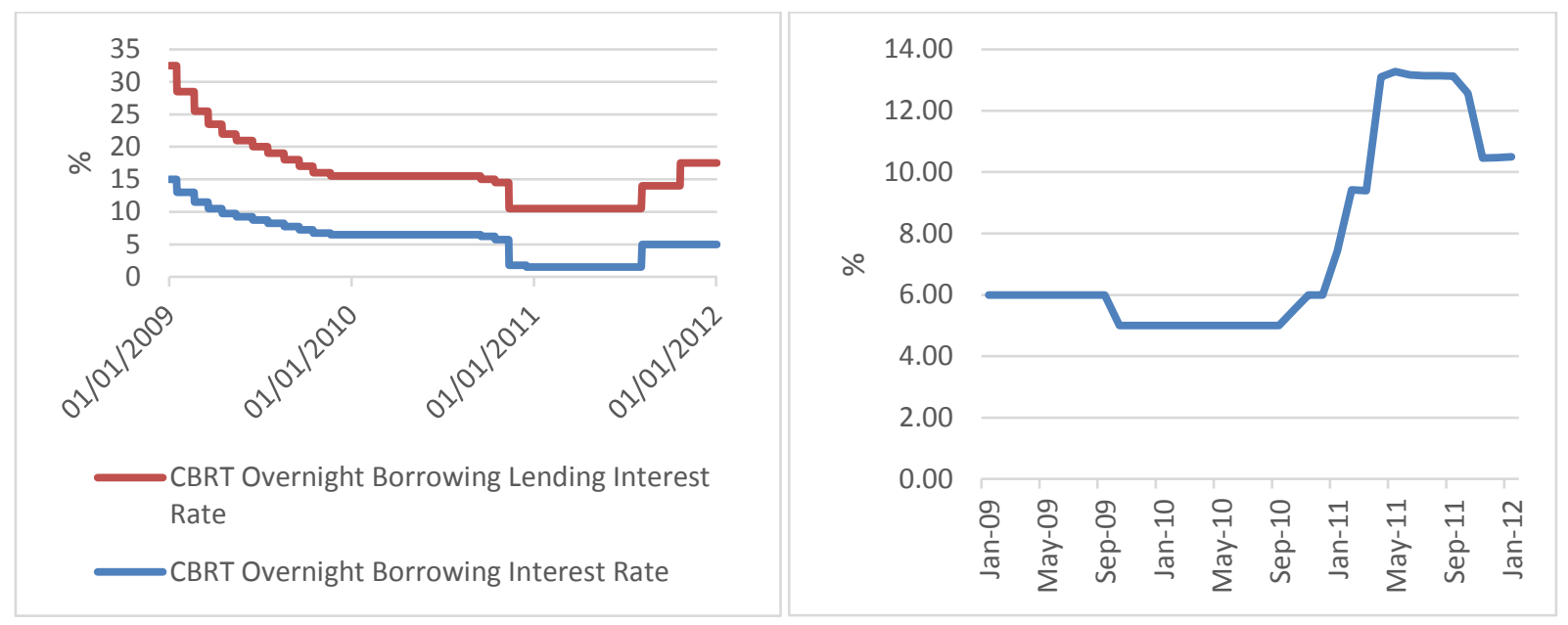

Figure 1. The Short Run Interest Rates of CBRT

Figure 2. The Effective Ratio of TL Required Reserves

Source : http://tcmb.gov.tr/wps/wcm/connect/en/tcmb+en, (Date of access : 13.02.2019).

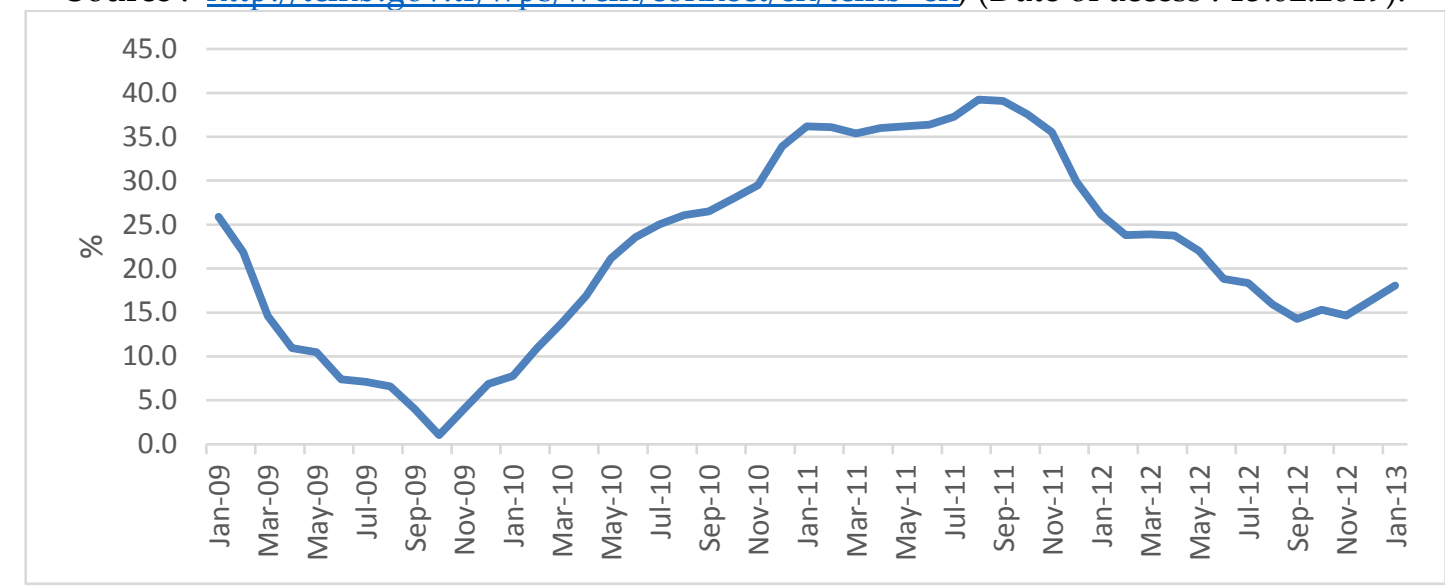

Figure 3. The Loan Growth Rate of Turkish Banking Sector

Source : BRSA Monthly Banking Sector Data. https://www.bddk.org.tr/BultenAylik/en, (Date of access : 15.02.2019).

\section{Macroprudential Policies Applied By Banking Regulation and Supervision Agency in Turkey}

The BRSA has simultaneously implemented macroprudential policies with the CBRT recently as an institution of regulation of the banking system. Thus, macro-prudential policies have been carried out in coordination with the CBRT in Turkey since the middle of 2011.

The macro-prudential regulations applied by the BRSA can be summarized chronologically. These regulations were used to establish the macro-prudential policy index, which is an explanatory variable in the econometric time series model that was described in fourth part of the paper. Firstly, let's list tightening macro-prudential tools in order to mitigate loan growth in Turkey since 2006.

As announced and effective since November 2006, banks' absolute value of "Net Foreign Exchange (FX) position (including off-balance-sheet items) to Total Equity" should not exceed 20\%.

\footnotetext{
2 The BRSA regulation dated 18.06.2011 https://www.bddk.org.tr/Legislation-Category/Regulations, Date of access : 25.02.2019. 
> Banks are required to maintain a "Total liquidity adequacy ratio" of 100\% calculated for next 7-day period and 31-day period. The regulation was effective for all banks initially since November 2006, but after it has been in force and effective only for development and investment banks since 2015.

$>$ Banks are required to maintain a "Foreign currency adequacy ratio" of $80 \%$ calculated for next 7-day period and 31-day period. The regulation was effective for all banks initially since November 2006, but after it has been in force and effective only for development and investment banks since 2015.

$>$ In accordance with Basel Criteria, Banks began allocating capital for operational risk since June 2007.

$>$ As announced and effective March 22, 2008 risk weights were increased to $150 \%$ from $100 \%$ at credit card receivables in the maturity of 6-12 months. Risk weights were increased to $200 \%$ from $100 \%$ at credit card receivables over the past 12 months.

> As announced and effective June 16, 2009 foreign exchange (FX) credits to residents in Turkey with an average maturity exceeding one year and with an amount no less than US\$5 million.

$>$ As announced and effective December 17, 2010 the minimum payout rate for newly allocated credit cards has been increased from $20 \%$ to $40 \%$. Moreover, minimum payout rates for credit cards with different limits were increased by 6 month intervals by the beginning of 2015 .

$>$ As effective January 1, 2011 mortgage loans can have a maximum loan-to-value (LTV) ratio of $80 \%$. This rate was $50 \%$ for commercial housing loans.

$>$ As announced and effective June 17,2011 , in a year, up to $50 \%$ of the term debt of credit cards that were paid up to three times of it was out of use.

$>$ As announced and effective June 18, 2011 risk weights were increased to $150 \%$ from $100 \%$ at consumer loans (apart from housing and vehicle loans) in the maturity of 1-2 years. Risk weights were increased to $200 \%$ from $100 \%$ at credit card receivables over the past 2 years.

$>$ As announced and effective June 18, 2011, BRSA began to carry out "increased general provisioning for consumer loans (apart from housing and vehicle loans).

$>$ As announced and effective October 8, 2013, the total credit card limit of an individual obtained from all card issuing organizations can't exceed twice of his monthly average net income for the first year and four times of the income for the second year and subsequent years. This is an important "loan-toratio" macro-prudential tool.

$>$ As announced and effective October 8, 2013, risk weights were increased to $100 \%$ from $75 \%$ at credit card receivables in the maturity of 1-6 months. Risk weights were increased to $200 \%$ from $150 \%$ at credit card receivables in the maturity of 6-12 months. . Risk weights were increased to $250 \%$ from $200 \%$ at credit card receivables over the past 12 months.

> As announced and effective October 8, 2013, risk weights were increased to $150 \%$ from $75 \%$ at vehicle loans in the maturity of 1-2 years. Risk weights were increased to $200 \%$ from $75 \%$ at credit card receivables over the past 2 years.

$>$ As announced and effective December 12, 2013, The maturity of vehicle loans was limited to 48 months. The maturity of consumer loans (apart from housing and vehicles loans) was limited to 36 months.

$>$ As effective January 1, 2014, banks have to meet a minimum leverage ratio. This ratio is calculating according to the Basel III standard and its minimum has to be $3 \%$.

$>$ As effective February 1, 2014, installment period was limited to 9 months with credit cards. The installment application of telecommunications, gasoline-liquid fuel, food, and jewellery was ended.

$>$ As effective January 1, 2014, banks have to meet a year-"capital conservation buffer" (ccob). Effective January 1, 2016, the ccob was introduced with a rate of 0,625\%. Effective January 1, 2017, the rate for the ccob was raised to $1,25 \%$. Effective January 1, 2018, the rate for the ccob was raised to $1,875 \%$. The buffer rate is gradually increasing parallel to Basel III process.

$>$ The regulation of "liquidity coverage ratio" has been effective since January 2005 (in line with the rules of the Basel III standard). This ratio must be at least $70 \%$ for year 2016 and it must be at least $80 \%$ for year 2017.

Secondly, it may be listed easing macro-prudential tools in order to boost loan growth in Turkey since 2006 : 
> Maximum loan-to-value (LTV) ratio of $50 \%$ for commercial housing loans has been abolished since April 4, 2013.

> General provisioning for export loans have reduced to zero since October 8, 2013. This rate has been reduced to half for SME (Small and Medium-sized) loans.

$>$ Installment application in white goods, furniture and education expenditures has been increased to 12 months since November, 25, 2015.

Disk weights have been reduced to 35\% from 50\% for mortgage loans since March 3, 2016.

> Risk weights have been begun to carry out $75 \%$ for consumer loans (apart from housing and vehicle loans) in every maturity since April 1, 2016.

$>$ Risk weights have been reduced to 75\% for vehicle loans in every maturity since April 1, 2016.

$>$ Mortgage loans can have a maximum loan-to-value (LTV) ratio for mortgage loans has been increased to $80 \%$ from $75 \%$ since September 6, 2016.

> BRSA has abolished the application of "increased general provisioning for consumer loans (apart from housing loans)" since September 27, 2016.

\section{Applied Literature on Empirical Analyses}

Cerutti, Claessens and Laeven (2015) use IMF survey, they document the use of macro-prudential policies for 119 countries over the 2000-2013 period, covering many instruments. They find that emerging economies use macro-prudential policies most frequently, especially foreign exchange related ones, while advanced countries use borrower-based policies more. According to the conclusion of paper, the effects of macro-prudential policies are less in financially more developed and open economies.

Claessens, Ghosh and Mihet (2014) use panel data regressions and they analyze how changes in balance sheets of some 2800 banks in 48 countries over 2000-2010. Firstly, they find that some macro-prudential policies reduce the growth of assets in banking sector. They also find that measures aimed at borrowers-debt to income (DTI) and loan to value (LTV)- and at financial institutions-limits on loan growth and foreign currency lending- are effective in reducing asset growth. According to the conclusion of paper, there are large differences across countries in the usage of macro-prudential policies, with emerging markets and closed capital account countries using these policies relatively more than advanced countries and open capital account countries.

Altunbaş, Binici and Gambacorta (2017) investigates the effects of macro-prudential policies on bank risk through a large panel of banks operating in 61 advanced and emerging market economies (EMEs). They use also information for 3177 banks operating in both advanced economies and EMEs over the period 1990-2012. They reveal that there are there main findings. First, there is evidence suggesting that macro-prudential tools have a significant impact on bank risk. Second, the responses to changes in macro-prudential tools differ among banks, depending on their specific balance sheet characteristics. Especially, banks that are small, weakly capitalized and with a higher share of wholesale funding react more strongly to changes in these tools. Third, macro-prudential policies seem more effective in a tightening than in an easing phase.

Erdem, Özen and Ünalmış (2017) use a data set of 30 countries and Panel Vector Autoregression (VAR) approach. They shed light on the effectiveness of such policy tools to curb or control domestic credit growth in case of a positive global liquidity shock in emerging market and developing countries. Panel data estimation results show that global liquidity shocks cause a different increase in domestic credit growth in emerging and developing economies. On the other hand, effectiveness of macro-prudential policies are more effective during credit expansion periods.

McDonald (2015) use a data set of 60 countries over the period 1990Q1-2014Q1. He reveals that the limits placed on loan to value (LTV) and debt to income (DTI) provide stability in the housing market. In this paper, the effects of LTV and DTI indicators on the housing sector, real credit growth and housing price inflation are analyzed. According to empirical results, tightening tools are more effective than easing ones. 


\section{Data Set and Empirical Analyses}

The empirical time series model is given by the following equation :

$$
Y t=\text { constant term }+\alpha * M P I t+\beta * M A C R O t+\theta * R R t+\pi * B S C t+A R \text { terms }+ \text { MA terms }+\epsilon_{t}
$$

The database includes 150 months that cover the period of 2006M1-2018M06 used as a time series to analyze the effects of the CBRT's new monetary policy and the BRSA's macro-prudential tools on loan growth of Turkish banking system. The data consist of three banking groups. These are the whole Turkish banking sector, deposit banking and development\&investment banking groups. These groups are analysed separately.

The variables in the equation express the logarithmic differences and $t$ is time (monthly data). $Y$ is the loan growth of the banking sector and represents the risk indicator of the banking system. $\mathrm{Y}$ is the dependent variable of the regression. In this paper; total loan, consumer loan and commercial loan are used as dependent variables of the banking sector. MPI represents macroprudential policy index, which is an explanatory variable. When consider that the MPI takes the value of +1 if a given macro-prudential tool was tightened and -1 if it was eased. (Altunbaş et al.,2017) We can look at MACRO, RR and BSC, respectively, represent macroeconomic variables, required reserve and bank specific characteristics. These are all the explanatory variables of the model. AR terms represent autoregression terms of the dependent variable. MA terms represent moving averages of the error terms. We can see the progress of MPI from Figure 4.

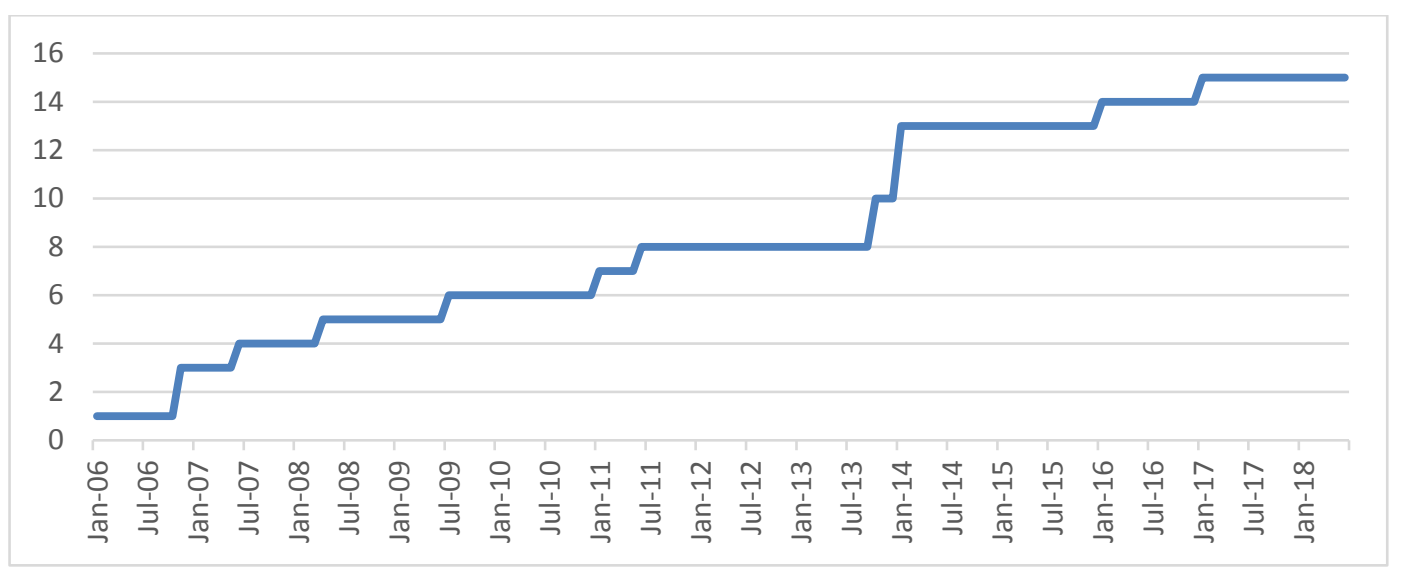

Figure 4. The Progress of the Macroprudential Index of Turkey

Source : Prepared by author.

We use three macro variables in our model. These are weighted average interest rate of the CBRT (int), real effective exchange rate (excr) and industrial production index (ipi). At the same time, we use four bank specific characteristics. These are the size of assets, capital adequacy ratio (car), ratio of loans to deposits and return on assets. Instead of using capital adequacy ratio, we use the ratio of total equity to total liabilities for development\&investment banks.

The CBRT has carried out a policy that fund the banking system with weighted average interest rate, which have daily frequency. Whereas the frequency of the interest rate data is daily, the other ones are announced on monthly. Therefore, the interest rate data has converted to the monthly frequency by taking the averages of 30 days. If macroeconomic time series have stochastic trend, the series have unit root.

The presence of unit root leads to spurious regression. According to Augmented Dickey Fuller test, we have found that the series contain unit root. When we used logarithmic differences of the series in the model, we have found that these new series are stationary. Therefore, logarithmic differences of the series have been used in the model. The unit root test results for the series in the model can be viewed from Table 1.

Data that has been used in the model obtained from the CBRT Electronic Data Delivery System (EDDS), Turkey Statistical Institute (TSI) database, the BRSA Turkish Banking Sector Interactive Monthly Bulletin and Reuters database. The model has been estimated in Eviews 9. 
H. Ardor - M. Mahmutoğlu 11/4 (2019) 2371-2383

Table 1. Augmented Dickey-Fuller Unit Root Test Results (probability value)

\begin{tabular}{|c|c|c|c|c|c|}
\hline Variable & Constant & Constant+Trend & Variable & Constant & Constant+Trend \\
\hline lntotalloan & 0,369 & 0,210 & $\mathrm{D}$ (Intotalloan) & $0,000^{* * *}$ & $0,000^{* * *}$ \\
\hline lnconsumerloan & $0,066^{*}$ & 0,897 & $\mathrm{D}$ (lnconsumerloan) & $0,0004^{* * *}$ & $0,0000^{* * *}$ \\
\hline lncommercialloan & 0,6534 & $0,079^{*}$ & $\mathrm{D}$ (lncommercialloan) & $0,0000^{* * *}$ & $0,00000^{* * *}$ \\
\hline MPI & 0,767 & 0,296 & $\operatorname{lnMPI}$ & $0,053^{*}$ & 0,349 \\
\hline $\operatorname{lnint}$ & 0,644 & 0,982 & $\mathrm{D}$ (lnint) & $0,000^{* * *}$ & $0,000^{* * * *}$ \\
\hline lnexcr & 0,701 & 0,161 & $\mathrm{D}($ lnexcr $)$ & $0,000^{* * *}$ & $0,000^{* * *}$ \\
\hline lnipi & 0,917 & 0,224 & $\mathrm{D}$ (lnipi) & $0,000^{* * *}$ & $0,000^{* * *}$ \\
\hline $\ln r$ & 0,237 & 0,112 & $\mathrm{D}(\ln r \mathrm{r})$ & $0,004^{* * *}$ & $0,020^{* *}$ \\
\hline lnasset & 0,868 & $0,005^{* * *}$ & $\mathrm{D}$ (lnasset) & $0,000^{* * *}$ & $0,000^{* * *}$ \\
\hline lncar & $0,039^{* *}$ & $0,043^{* *}$ & $\mathrm{D}$ (lncar) & $0,000^{* * *}$ & $0,000^{* * *}$ \\
\hline lnloantodep & 0,184 & 0,677 & $\mathrm{D}$ (loantodep) & $0,000^{* * *}$ & $0,000^{* * *}$ \\
\hline lnreturntoasset & 0,552 & 0,556 & $\mathrm{D}$ (lnreturntoasset) & $0,024^{* *}$ & $0,089^{*}$ \\
\hline
\end{tabular}

The symbols ${ }^{*}, * *{ }^{* * *}$ represent significance levels of $10 \%, 5 \%, 1 \%$ respectively.

\section{Main Regression Results}

When we have estimated the model with the ordinary least squares (OLS) and have performed Lagrange Multiplier (LM) serial correlation test for the autocorrelation between the errors of the model, we have found that there is an autocorrelation problem between the errors of the regression. Besides, we have performed Breusch-Pagan-Godfrey and White Heteroscedasticty tests, we have found that the errors of the model are not homoscedasticty. For these reason, we have estimated the regression with ARMA Generalized Least Squares (GLS). When we have investigated that Correlogram-Q statistics and Schwarz criteria, we have found the optimum model with AR and MA terms.

Table 2 shows that the effects of macroprudential tools on the loan growth. The coefficient on the MP index is negative and significant, indicating that a tightening of macro-prudential policy reduces the loan growth. However, the magnitude of the coefficient is relatively small. Moreover, the coefficients of the weighted average interest rate (lnint) and real effective exchange rate (lnexcr) are not significant. The Industrial Production Index (lnipi) is positively correlated with the loan growth. Required reserves (lnrr) and capital adequacy ratio (car) are negatively coefficient with the loan growth. The coefficients of these variables are also significant. The coefficients of total assets (lnasset) and loan to deposit are not only positive and significant, but also the magnitudes of these coefficients are high.

Table 2 also shows that the effects of macro-prudential tools on the consumer loan growth and commercial loan growth. The coefficient on the MP index is negative and significant indicating that a tightening of macroprudential policy reduces the consumer loan growth. Nevertheless, the magnitude of the coefficient is relatively small. The coefficient on the MP index is not significant for commercial loan growth.

The adjusted coefficients of determination are, respectively, $0,853,0,676$ and 0,855 . Therefore we can say that the explanatory variables have a high total effect on dependent variables. 
H. Ardor - M. Mahmutoğlu 11/4 (2019) 2371-2383

Table 2. Main Regression Results of the Turkish Banking Sector

\begin{tabular}{|c|c|c|c|c|c|c|}
\hline & \multicolumn{2}{|c|}{ D(ln Total Loans) } & \multicolumn{2}{c|}{ D(ln Consumer Loans) } & \multicolumn{2}{c|}{ D(ln Commercial Loans) } \\
\hline & Coefficient & Prob. & Coefficient & Prob. & Coefficient & Prob. \\
\hline Constant & 0,0166 & $0,0000^{* * *}$ & 0,0322 & $0,0000^{* * *}$ & 0,0106 & $0,0007^{* * * *}$ \\
\hline lnMPI & $-0,0035$ & $0,0034^{* * *}$ & $-0,0087$ & $0,0000^{* * *}$ & $-0,0019$ & 0,1459 \\
\hline D(lnint) & $-0,0043$ & 0,6386 & $-0,0002$ & 0,8486 & 0,0046 & 0,6354 \\
\hline D(lnexcr) & $-0,0370$ & 0,1065 & 0,0117 & 0,6468 & $-0,0840$ & $0,0025^{* * *}$ \\
\hline D(lnipi) & 0,0451 & $0,0676^{*}$ & 0,0542 & $0,0259^{* * *}$ & 0,0394 & 0,2124 \\
\hline D(lnrr) & $-0,0316$ & $0,0114^{* *}$ & 0,0021 & 0,8681 & $-0,0313$ & $0,0320^{* *}$ \\
\hline D(lnasset) & 0,5265 & $0,0000^{* * *}$ & 0,0870 & $0,0294^{* *}$ & 0,7259 & $0,0000^{* * *}$ \\
\hline D(lncar) & $-0,1708$ & $0,0000^{* * *}$ & $-0,0928$ & $0,0017^{* * *}$ & $-0,1782$ & $0,0000^{* * *}$ \\
\hline D(loantodep) & 0,1347 & $0,0073^{* * *}$ & 0,0803 & 0,1140 & 0,2253 & $0,0005^{* * *}$ \\
\hline D(lnreturntoasset) & 0,0014 & $0,0291^{* *}$ & 0,0018 & $0,0075^{* * *}$ & & \\
\hline AR(1) & 0,2529 & $0,0064^{* * *}$ & 0,5721 & $0,0000^{* * *}$ & & \\
\hline AR(2) & 0,2077 & $0,0152^{* *}$ & & & & \\
\hline AR(3) & & & & & 0,2425 & $0,0035^{* * *}$ \\
\hline AR(5) & & & & & 0,2093 & $0,0120^{* *}$ \\
\hline
\end{tabular}

The symbols *,***** represent significance levels of $10 \%, 5 \%, 1 \%$ respectively.

Table 3 shows that the effects of macro-prudential tools on the loan growth for the Turkish Deposit Banking Group. The coefficient on the MP index is negative and significant, indicating that a tightening of macroprudential policy reduces the loan growth. However, the magnitude of the coefficient is relatively small. The coefficients of the weighted average interest rate (lnint), real effective exchange rate (lnexcr), the Industial Production Index (Inipi) and Required reserves (lnrr) are not significant. Capital adequacy ratio (car) is negatively coefficient with the loan growth and the coefficient of it is significant. The coefficients of total assets (lnasset) and loan to deposit are not only positive and significant, but also the magnitudes of these coefficients are high. We have estimated the regression with ARMA Generalized Least Squares (GLS).

Table 3. Main Regression Results of the Turkish Deposit Banks

\begin{tabular}{|c|c|c|}
\hline & \multicolumn{2}{|c|}{ D(ln Total Loans) } \\
\hline & Coefficient & Prob. \\
\hline Constant & 0,0167 & $0,0000^{* * *}$ \\
\hline InMPI & $-0,0034$ & $0,0035^{* * *}$ \\
\hline D(lnint) & 0,0032 & 0,7525 \\
\hline D(lnexcr) & $-0,0026$ & 0,9296 \\
\hline D(lnipi) & 0,0491 & 0,1360 \\
\hline D(lnrr) & $-0,0108$ & 0,4822 \\
\hline D(lnasset) & 0,4737 & $0,0000^{* * *}$ \\
\hline D(lncar) & $-0,1644$ & $0,0000^{* * *}$ \\
\hline D(loantodep) & 0,1557 & $0,0143^{* *}$ \\
\hline D(lnreturntoasset) & 0,0012 & 0,1555 \\
\hline AR(3) & 0,2042 & $0,0179^{* *}$ \\
\hline
\end{tabular}

The symbols $*{ }^{* *},{ }^{* * *}$ represent significance levels of $10 \%, 5 \%, 1 \%$ respectively.

Table 4 shows that the effects of macro-prudential tools on the loan growth for the Turkish Development\&Investment Banking Group. Unlike the results of banking sector and deposit banking group, the coefficient on the MP index is not significant statistically. The real effective exchange rate (lnexcr) is negatively coefficient with the loan growth and the coefficient of it is significant statistically. The other macroeconomic variables are insignificant. Unlike the other regressions, instead of using capital adequacy 
ratio, we utilize the ratio total equity to total liabilities in the regression. Unlike the other regressions, there are moving average (MA) terms as an explanatory variables.

Table 4. Main Regression Results of the Turkish Development\&Investment Banks

\begin{tabular}{|c|c|c|}
\hline & \multicolumn{2}{|c|}{ D(ln Total Loans) } \\
\hline & Coefficient & Prob. \\
\hline Constant & 0,0108 & $0,0000^{* * *}$ \\
\hline D(lnMPI) & $-0,0004$ & 0,8507 \\
\hline D(lnint) & $-0,0089$ & 0,5029 \\
\hline D(lnexcr) & $-0,1296$ & $0,0036^{* * *}$ \\
\hline D(lnipi) & $-0,0523$ & 0,3611 \\
\hline D(lnasset) & 0,5017 & $0,0002^{* * *}$ \\
\hline D(lnequityliab) & $-0,1720$ & 0,1041 \\
\hline AR(1) & 0,6729 & $0,0011^{* * *}$ \\
\hline AR(2) & $-0,4527$ & $0,0554^{*}$ \\
\hline MA(1) & $-0,8097$ & $0,0000^{* * *}$ \\
\hline MA(2) & 0,7298 & $0,0001^{* * *}$ \\
\hline
\end{tabular}

The symbols ${ }^{*}, * *{ }^{* * *}$ represent significance levels of $10 \%, 5 \%, 1 \%$ respectively.

\section{Conclusion}

After the global financial crisis, developed countries implemented highly expansionary monetary policies. After 2009, since interest rates are relatively low in these countries, there was quite high levels of capital inflows to Turkey. These quite capital inflows cause to overvalue the Turkish Lira. This economic situation caused high capital account deficits and excessive loan growth in the banking system. The high rate of loan growth in the banking sector and the high-unsustainability of current account deficits have all given rise to financial fragility threats to financial stability in Turkey. In our paper, we acknowledge that the excessive loan growth of the banking system is the indicator of financial fragility. After 2009, the new monetary policy of the CBRT and the macro-prudential policies of the BRSA mutually aimed to mitigate financial vulnerabilities and provide financial stability in Turkey. When we examine and interpret the empirical results of this paper, we can say that the macro-prudential policy tools affect a certain degree of credit growth in the whole banking system. However, this effect is not very strong. Moreover, when we investigate the empirical results for only development and investment banking specifically, we can't detect this effect.

When we take into account some macroeconomic and financial indicators and population level of Turkey, the study reveal that the number of banks that actively operate is relatively low and the Turkish banking system has an oligopolistic structure. This situation creates some monopolistic property in determining the loan and deposit rates. Moreover, Turkey is a country that has chronic savings deficit. Therefore the currency substitution phenomenon is quite high in Turkey. The ratio of foreign exchange (FX) loans to total loans and the ratio of FX deposits to total deposits are quite higher than developed countries. Because of all these characteristics, some regulations such as macro-prudential policies regarding the banking sector may not give results like developed countries where the banking sector is more competitive. According to this paper's empirical results, the tightening macro-prudential policies reduce the loan growth of the banking sector, so there is some extent that the effects of the macro-prudential policies on the loan growth of the banking system, but this effect is not so strong. 


\section{References}

Alper K. , Binici, M. , Demiralp S. , Kara H. , Özlü P. (2014) : Reserve Requirements Liquidity Risk and Credit Growth, CBRT Working Paper, No : 14/24, 17-22.

Altunbaş, Y. , Binici, M. and Gambacorta L. (2017) : Macro-prudential Policy and Bank Risk, Bank for International Settlement (BIS) Working Papers, No:646, 7-9.

Aslaner O. , Çıplak U. , Kara H. , Küçüksaraç D. (2014) : Reserve Option Mechanism : Does It Work As An Automatic Stabilizer? , CBRT Working Paper, No : 14/38, 3-4.

Asteriou D. , Hall S. (2007) Applied Econometrics, A Modern Approach Using Eviews and Microfit Revised Edition, 229-247.

Aysan A. , Fendoğlu S. , Kılınç M. (2014) : Managing Short Term Capital Flows in New Central Banking : Unconventional Monetary Policy Framework in Turkey , CBRT Working Paper, No : 14/03, 7-12.

Başçı, E. , Kara, H, (2011) : Financial Stability and Monetary Policy, CBRT Working Paper, No : 11/8, 4-6.

Binici, M. , Erol, H. , Kara, H. , Özlü, P. , Ünalmış, İ. (2013) : Can Interest Rate Corridor Be A Macro-Prudential Tool?, CBRT Research Notes in Economics, No : 13/20, 4-14.

Binici, M. , Erol, H. , Kara, H. , Özlü, P. (2016) : Interest Rate Corridor and Bank Interest Rates : Some Findings About Monetary Transmission Mechanism, , CBRT Working Paper, No :16/08.

BRSA (2015) Implementing Regulation on Measurement and Evaluation of Banks in Capital Adequacy.

Central Bank of Turkish Republic (CBRT) Financial Stability Report, November 2018, Volume 27, 6-8.

Cerutti, E. , Claessens, S. and Laeven, L. (2015) : The Use and Effectiveness of Macro-prudential Policies : New Evidence, IMF Working Paper, No :15/61, 6-7.

Claessens, S. , Ghosh, S. , Milet, R. (2015) : Macro-Prudential Policies to Mitigate Financial System Vulnerabilites, IMF Working Paper, No : 14/155, 3-10.

Değerli, A. ,Fendoğlu, S. (2013) : Reserve Option Mechanism As a Stabilizing Policy Tool : Evidence from Exchange Rate Expectations, CBRT Working Paper, No : 13/28, 4-6.

Dimitrios A. , Hall, S. (2007) . Applied Econometrics A Modern Approach Using Eviews and Microfit Revised Edition, Palgrave Macmillan, 229-247.

Erdem, P. , Özen, E. , Ünalmış, İ.(2017) : Are Macro-Prudential Policies Effective Tools to Reduce Credit Growth in Emerging Markets?, CBRT Working Paper, No : 17/12, 2-5.

Gujarati D. ; Basic Econometrics, United Stated Military Academy, West Point, Mc Graw Hill, Fourth Edition, 2003, 835-848.

McDonald, C. (2015). When is Macro-Prudential Policy Effective?, BIS Working Paper, No : 496, 2-4.

Kara, H. (2012) : The Monetary Policy After The Global Crises, CBRT Working Paper, No : 12/17, 2-13.

Kara, H. (2015) : Interest Rate Corridor and The Monetary Policy, CBRT Research Notes in Economics", No : 15/13, 3-11.

Lutkepohl, H. (2005) ; New Introduction to Multiple Time Series Analyses, Springer Berlin Heildelberg New York, 1-5, 31-39.

Oduncu A. , Ermişoğlu E. , Polat T. (2013) The Effect of CBRT's New Policy Mix on the Volatility of Credit Growth , CBRT Research Notes in Economics, No : 2013-27, 3-4.

Özatay F. (2011) : The New Monetary Policy of the Central Bank of Turkey : Two Targets-Three Intermediate Targets-Three Tools, İşletme, İktisat, Finans 26 (302), 28-39.

Özatay F. (2012) : New Search of The New Monetary Policy and CBRT , Economic Policy Research Foundation of Turkey (TEPAV) Report, 10-14. 
H. Ardor - M. Mahmutoğlu 11/4 (2019) 2371-2383

Özdemir, A. (2015) : Interest Rate Surprises and Transmission Mechanism in Turkey : Evidence From Impulse Response Analyses. TCMB Working Paper No: 15/04, 1-15.

The IMF's Annual Macroprudential Policy Survey-Objectives, Design and Country Responses, IMF Policy Paper, April 2018, 6-8.

US, V. (2016) : Determiners of Non-Performing Loans in the Turkish Banking Sector : What Has Changed After the Global Crisis?, CBRT Research Notes in Economics, No: 16/27, 3-8. 


\section{APPENDIX}

Table 5. Summary Statistics of Main Regression Variables

$\begin{array}{lllll}\text { Mean } & \text { Median } \quad \text { Min } \quad \text { Max } & \begin{array}{l}\text { Standard } \\ \text { Deviation }\end{array} & \begin{array}{l}\text { Number of } \\ \text { Observations }\end{array}\end{array}$

Dependent Variables*

$\begin{array}{lllllll}\text { D(ln Total Loans) } & 0,0183 & 0,0175 & -0,0148 & 0,1018 & 0,0160 & 149 \\ \text { D(ln Consumer Loans) } & 0,0159 & 0,0145 & -0,0080 & 0,0822 & 0,0125 & 149 \\ \text { D(ln Commercial Loans) } & 0,0192 & 0,0174 & -0,0278 & 0,1110 & 0,0198 & 149 \\ \text { Independent Variables } & & & & & & \\ \text { MPI } & 8,6711 & 8,0000 & 1,0000 & 15,0000 & 4,3859 & 149 \\ \text { D(lnint) } & 0,0003 & 0,0000 & -0,1744 & 0,2942 & 0,0640 & 149 \\ \text { D(lnexcr) } & -0,0029 & -0,0002 & -0,1100 & 0,0615 & 0,0274 & 149 \\ \text { D(lnipi) } & 0,0032 & 0,0038 & -0,0606 & 0,0698 & 0,0201 & 149 \\ \text { D(lnrr) } & 0,0035 & 0,0000 & -0,1834 & 0,3327 & 0,0452 & 149 \\ \text { D(lnasset) } & 0,0150 & 0,0143 & -0,0241 & 0,0735 & 0,0179 & 149 \\ \text { D(lncar) } & -0,0026 & -0,0021 & -0,1681 & 0,0620 & 0,0268 & 149 \\ \text { D(loantodep) } & 0,0044 & 0,0043 & -0,0389 & 0,0347 & 0,0110 & 149\end{array}$

*It contains the variables of whole Turkish Banking sector. 